\title{
Inhaled corticosteroids and Churg-Strauss syndrome: a report of five cases
}

\author{
C. Le Gall*, S. Pham*, S. Vignes ${ }^{+}$, G. Garcia*, H. Nunes*, D. Fichet ${ }^{++}$, \\ G. Simonneau*, P. Duroux*, M. Humbert*
}

\begin{abstract}
Inhaled corticosteroids and Churg-Strauss syndrome: a report of 5 cases. C. Le Gall, S. Pham, S. Vignes, G. Garcia, H. Nunes, D. Fichet, G. Simonneau, P. Duroux, M. Humbert. ERS Journals Ltd 2000.

ABSTRACT: Churg-Strauss syndrome is an eosinophil-associated, small vessel granulomatous vasculitis, characterized by late onset asthma, upper airways disease, eosinophilia, and clinical manifestations of systemic vasculitis. Several cases of ChurgStrauss syndrome have been recognized in patients treated with cysteinyl leukotrienereceptor antagonists and weaned off systemic corticosteroids. These cases have led to a general warning on the possible development of Churg-Strauss syndrome after taking cysteinyl leukotriene-receptor antagonists.

The authors report five cases of Churg-Strauss syndrome in severe steroid dependent asthmatics in whom inhaled corticosteroids allowed systemic corticosteroid withdrawal. It is concluded that physicians should monitor patients carefully when severe asthma is controlled with any substance allowing withdrawal from (or even avoidance) of systemic corticosteroids.
\end{abstract}

Case-control studies should identify more precisely the risk factors of ChurgStrauss syndrome.

Eur Respir J 2000; 15: 978-981.

Churg-Strauss syndrome is an eosinophil-associated, small vessel granulomatous vasculitis, characterized by late onset asthma, upper airways disease, eosinophilia, and clinical manifestations of systemic vasculitis [1-4]. Extrapulmonary manifestations include weight loss, myalgia, arthralgia, skin signs, mononeuritis multiplex, gastrointestinal tract involvement, and cardiomyopathy [1-4]. In 1990 the American College of Rheumatology promulgated specific diagnostic criteria for the syndrome [4]. For a diagnosis of Churg-Strauss syndrome to be made patients must present with at least four of the following six features: 1) moderate to severe asthma; 2) peripheral blood eosinophilia $(>10 \%)$; 3 ) mononeuropathy or polyneuropathy; 4) nonfixed pulmonary infiltrates; 5) paranasal sinus abnormality; and 6) a biopsy specimen containing a blood vessel with extravascular eosinophils.

Recently, Churg-Strauss syndrome has received much attention because of several reports of the syndrome in patients taking recently approved asthma drugs belonging to the family of the cysteinyl leukotriene (LT)-receptor antagonists (zafirlukast, montelukast, and pranlukast) [515]. These cases have led to a general warning on the possible association of Churg-Strauss syndrome with LT receptor antagonists $[9,15]$. However, careful analysis of all reported cases suggests that Churg-Strauss syndrome develops primarily in those patients taking these medications who had an underlying eosinophilic disorder that was being masked by corticosteroid treatment and unmasked by novel asthma medication-mediated corticosteroid withdrawal [15]. In the present report, five cases
* Service de Pneumologie et Réanimation Respiratoire, Hôpital Antoine-Béclère, Clamart, France. ${ }^{\text {T }}$ Service de Pneumologie, Centre Hospitalier de Dreux, France. Service d'Immuno-hématologie, Hôpital Saint-Louis, Paris, France.

Correspondence: M. Humbert Service de Pneumologie et Réanimation Respiratoire Hôpital Antoine Béclère 157 rue de la Porte de Trivaux 92140 Clamart France Fax: 33146303824

\section{Keywords: Asthma}

Churg-Strauss syndrome

corticosteroids

inhaled corticosteroids

Received: January 272000

Accepted after revision February 252000 of Churg-Strauss syndrome are described in severe steroid-dependent asthmatics in whom inhaled corticosteroids allowed oral corticosteroid withdrawal.

\section{Case reports}

The patients discussed in this paper are detailed in the tables 1-3. They all suffered from severe persistent asthma requiring long-term oral corticosteroids to control their respiratory symptoms (range 3-216 months, mean 67 months). High-dose inhaled corticosteroids were initiated to improve asthma control and decrease systemic corticosteroid therapy on average 33 months before the onset of Churg-Strauss syndrome (range 10-84 months). When high-dose inhaled corticosteroids were started, there was no evidence of an underlying Churg-Strauss syndrome, as defined by the 1990 American College of Rheumatology criteria [4] (one patient had three criteria, two had two, and two had only one). Inhaled corticosteroids allowed the withdrawal of systemic corticosteroids 6-83 months (mean 31 months) before the diagnosis of Churg-Strauss syndrome. No patient received LT modifiers to control their asthma symptoms.

In all patients the diagnosis of Churg-Strauss syndrome could be established according to the criteria of the American College of Rheumatology [4]. Asthma, eosinophilia $>10 \%$, and paranasal sinus abnormalities were found in all patients. Neuropathy was identified in three out of five patients. Weight loss and fatigue were always present. 
Table 1. - Patient information

\begin{tabular}{|c|c|c|c|c|c|}
\hline & Patient 1 & Patient 2 & Patient 3 & Patient 4 & Patient 5 \\
\hline Sex/age yrs & $\mathrm{F} / 62$ & $\mathrm{M} / 62$ & $\mathrm{~F} / 53$ & $\mathrm{M} / 65$ & $\mathrm{M} / 76$ \\
\hline $\begin{array}{l}\text { Duration of oral corticosteroid } \\
\text { therany months }\end{array}$ & 30 & 60 & 24 & 3 & 216 \\
\hline $\begin{array}{l}\text { Total cumulative and mean daily } \\
\text { dose of oral prednisolone mg }\end{array}$ & $\begin{array}{c}23000 \\
25.5\end{array}$ & $\begin{array}{c}13500 \\
7.5\end{array}$ & $\begin{array}{c}5500 \\
7.5\end{array}$ & $\begin{array}{c}1700 \\
19\end{array}$ & $\begin{array}{c}16200 \\
2.5\end{array}$ \\
\hline Inhaled corticosteroids & Fluticasone & Fluticasone & Fluticasone & $\begin{array}{l}\text { Budesonide } \\
\text { dipropionate }\end{array}$ & Budesonide \\
\hline $\begin{array}{l}\text { Delay between initiation of inhaled } \\
\text { corticosteroid and diagnosis of } \\
\text { Churg-Strauss syndrome months }\end{array}$ & 10 & 10 & 27 & 84 & 33 \\
\hline $\begin{array}{l}\text { Dose of inhaled corticosteroid at the } \\
\text { time of Churg-Strauss syndrome diagnosis } \mu \mathrm{g}\end{array}$ & 2000 & 2000 & 500 & 1500 & 1600 \\
\hline $\begin{array}{l}\text { Delay between oral corticosteroid withdrawal } \\
\text { and diagnosis of Churg-Strauss syndrome months }\end{array}$ & 7 & 6 & 24 & 83 & 33 \\
\hline
\end{tabular}

F: female; M: male.

Conversely, cardiac involvement was rarely identified (one pericarditis). Erythrocyte sedimentation rate was elevated in all cases. Positive antineutrophil cytoplasmic antibodies was positive in one case. All patients improved with therapy consisting of systemic corticosteroids in all patients associated with cyclophosphamide in two cases.

\section{Discussion}

Glucocorticosteroids (also known as corticosteroids or steroids) are the most effective drugs in the treatment of asthma [16-18]. Oral corticosteroids are still very useful for the control of asthma exacerbations but their chronic use has sharply declined with the introduction of inhaled corticosteroids that give effective asthma control with few systemic side-effects [16-18]. However, a major concern in patients taking oral or high-dose inhaled corticosteroids is still the side-effects associated with long-term maintenance therapy such as increased bone turnover, impaired growth, hypothalamic-pituitary-adrenal suppression, cataract, increased blood glucose, skin bruising, and psychiatric disturbance [16-18]. Therefore much attention has been given to drugs with corticosteroid-sparing effects [19]. Indeed, drugs such as methotrexate, cyclosporin and gold can usefully reduce the dose of oral corticosteroids in some patients [19]. However, these agents can induce severe side-effects and are rarely used in asthma.

The cysteinyl LT $\mathrm{LTC}_{4}, \mathrm{LTD}_{4}$, and $\mathrm{LTE}_{4}$ are proinflammatory agents that can induce bronchoconstriction, increase vascular permeability, increase mucus production, and induce inflammatory cell infiltration of lung tissue. LT modifiers have recently become available on the market (cysteinyl $\mathrm{LT}_{1}$ receptor antagonists such as zafirlukast, montelukast and pranlukast, as well as the 5-lipoxygenase inhibitor, zileuton). Although these drugs are usually safe and well tolerated, some side-effects have been detected after approval for use in larger population samples [15]. Liver function abnormalities have been reported with zileuton. Moreover, $>50$ cases of Churg-Strauss syndrome have been published or reported to drug agencies in association with cysteinyl LT1 receptor antagonists in severe steroiddependent asthmatics who had discontinued oral corticosteroid a few months before development of the syndrome [5-15]. A few cases of the syndrome have also been described after zafirlukast in patients not receiving systemic steroid treatment [12]. The high incidence of such a rare entity [11] during the commercial postmarketing surveillance of cysteinyl $\mathrm{LT}_{1}$ receptor antagonists has led to a general warning that Churg-Strauss syndrome may occur after taking these drugs $[9,15]$.

There may however, be confusion between a direct drug side-effect and an unanticipated consequence of a decrease in corticosteroid therapy $[9,15]$. Interestingly, similar cases have been described with other medications in the past, emphasizing the fact that Churg-Strauss syndrome may be the mere consequence of corticosteroid withdrawal (or avoidance) in patients with an underlying vasculitis using an otherwise effective asthma drug [10, 15]. Indeed, the number of asthmatic people at risk of developing Churg-Strauss syndrome after the introduction of corticosteroid-sparing drugs is substantial, and physicians

Table 2. - Churg-Strauss criteria (1990 American College of Rheumatology [4]) at the time of initiation of inhaled corticosteroid therapy

\begin{tabular}{|c|c|c|c|c|c|}
\hline & Patient 1 & Patient 2 & Patient 3 & Patient 4 & Patient 5 \\
\hline Asthma & + & + & + & + & + \\
\hline Peripheral blood eosinophilia $>10 \%$ & - & - & - & - & $\begin{array}{l}18 \% \\
1870\end{array}$ \\
\hline Nonfixed pulmonary infiltrates & - & - & - & - & - \\
\hline Paranasal sinus abnormality & + & - & + & - & + \\
\hline Neuropathy & - & - & - & - & - \\
\hline Necrotizing vasculitis with extravascular eosinophil granulomas & NA & NA & NA & NA & NA \\
\hline
\end{tabular}

Values are presented as percentages and absolute numbers per cubic millimetre. + present; -: absent; NA: not available. 
Table 3. - Clinical and paraclinical findings at the time of Churg-Strauss syndrome diagnosis

\begin{tabular}{|c|c|c|c|c|c|}
\hline & Patient 1 & Patient 2 & Patient 3 & Patient 4 & Patient 5 \\
\hline Asthma & + & + & + & + & + \\
\hline Peripheral blood & $49 \%$ & $55 \%$ & $55 \%$ & $45 \%$ & $25 \%$ \\
\hline eosinophilia $>10 \%$ & 6000 & 18200 & 7500 & 12000 & 2700 \\
\hline $\begin{array}{l}\text { Nonfixed pulmonary } \\
\text { infiltrates }\end{array}$ & + & + & - & - & + \\
\hline $\begin{array}{l}\text { Paranasal sinus } \\
\text { abnormality }\end{array}$ & + & + & + & + & + \\
\hline Neuropathy & + & - & + & + & - \\
\hline $\begin{array}{l}\text { Necrotizing vasculitis } \\
\text { with extravascular } \\
\text { eosinophil granulomas }\end{array}$ & NA & NA & NA & + & NA \\
\hline Other & $\begin{array}{l}\text { Weight loss, } \\
\text { fatigue, } \\
\text { pleural effusion }\end{array}$ & $\begin{array}{l}\text { Weight loss, } \\
\text { fatigue, } \\
\text { pleural effusion, } \\
\text { myalgia }\end{array}$ & $\begin{array}{l}\text { Weight loss, } \\
\text { fatigue, } \\
\text { abdominal pain, } \\
\text { skin rash, } \\
\text { arthralgia }\end{array}$ & $\begin{array}{l}\text { Weight loss, } \\
\text { fatigue, } \\
\text { skin rash, } \\
\text { arthralgia, } \\
\text { myalgia }\end{array}$ & $\begin{array}{l}\text { Weight loss, } \\
\text { fatigue, } \\
\text { pericarditis, } \\
\text { abdominal pain, } \\
\text { oesophageal } \\
\text { ulceration }\end{array}$ \\
\hline
\end{tabular}

Values are presented as percentages and absolute numbers per cubic millimetre. + present; -: absent; NA: not available.

should monitor patients carefully when such therapies are prescribed, especially in patients with a history of severe asthma, eosinophilia, and sinusitis [15]. CHURG et al. [20] have previously reported the appearance of Churg-Strauss syndrome in steroid-dependent asthmatics whose corticosteroids were decreased or eliminated. CHURG et al. [20] named this disorder formes-frustes (incomplete) of ChurgStrauss syndrome to show that steroid therapy was suppressing or preventing the underlying vasculitic disease. The current report documents five new cases of formesfrustes of Churg-Strauss syndromes in patients weaned of oral corticosteroids thanks to the use of high doses of inhaled corticosteroids. Interestingly, these cases involved the most commonly prescribed inhaled corticosteroids for severe asthma in France (fluticasone, beclomethasone dipropionate and budesonide), suggesting that the present observations do not reflect hypersensitivity to a specific drug. This report also emphasizes the fact that inhalation of corticosteroids, even at high doses (500-2,000 $\mu \mathrm{g}$ fluticasone), cannot prevent the occurrence of formes-frustes of Churg-Strauss syndrome. On the other hand a recent report suggests that discontinuation of high-dose inhaled corticosteroids may have a role in triggering an underlying vasculitis in some patients, indicating possible control of Churg-Strauss vasculitis with high-dose inhaled corticosteroids [21].

Several hypotheses have been proposed in the past to explain the occurrence of Churg-Strauss syndrome in selected patient populations. The most widely used explanation remains that oral corticosteroid withdrawal unmasks an underlying systemic vasculitis. The recent controversy on cases of the syndrome putatively induced by cysteinyl leukotriene $_{1}$ receptor antagonists clearly emphasizes the need for case-control studies to clarify the respective roles of drugs, steroid withdrawal and other factors in the development of Churg-Strauss syndrome [15, 22].

\section{References}

1. Lanham JG, Elkon KB, Pusey CD, et al. Systemic vascu- litis with asthma and eosinophilia: a clinical approach to the Churg-Strauss syndrome. Medicine 1984; 63: 65-81.

2. Guillevin L, Cohen P, Gayraud M, Lhote F, Jarousse B, Casassus P. Churg-Strauss syndrome: clinical study and long-term follow-up of 96 patients. Medicine 1999; 78: 26-37.

3. Cottin V, Cordier J-F. Churg-Strauss syndrome. Allergy 1999; 54: 535-551.

4. Masi AT, Hunter GG, Lie JT, et al. The American College of Rheumatology 1990 criteria for the classifiacation of Churg-Strauss syndrome (allergic granulomatosis and angiitis). Arthritis Rheum 1990; 33: 1094-1100.

5. Wechsler ME, Garpestad E, Flier SR, et al. Pulmonary infiltrates, eosinophilia, and cardiomyopathy following corticosteroid withdrawal in patients with asthma receiving zafirlukast. JAMA 1998; 279: 455-457.

6. Knoell DL, Lucas J, Allen JN. Churg-Strauss syndrome associated with zafirlukast. Chest 1998; 114: 332-334.

7. Katz RS, Papernik M. Zafirlukast and Churg-Strauss syndrome. JAMA 1998; 279: 1949.

8. Holloway J, Ferriss J, Groff J, et al. Churg-Strauss syndrome associated with zafirlukast. $J$ Am Osteopath Assoc 1998; 98: 275-278.

9. Churg A, Churg J. Steroids and Churg-Strauss syndrome. Lancet 1998; 352: 32-33.

10. D'Cruz DP, Barnes NC, Lockwood CM. Difficult asthma or Churg-Strauss syndrome? Br Med J 1999; 318: 475476.

11. Stirling RG, Chung KF. Leukotriene antagonists and Churg-Strauss syndrome: the smoking gun. Thorax 1999; 54: 865-866.

12. Green RL, Vayonis AG. Churg-Strauss syndrome after zafirlukast in patients not receiving systemic steroid treatment. Lancet 1999; 353: 725-726.

13. Franco J, Artes MJ. Pulmonary eosinophilia associated with montelukast. Thorax 1999; 54: 558-560.

14. Kinoshita M, Shiraishi T, Koga T, Ayabe M, Rikimaru T, Oizumi K. Churg-Strauss syndrome after corticosteroid withdrawal in an asthmatic patient treated with pranlukast. J Allergy Clin Immunol 1999; 140: 534-535.

15. Wechsler ME, Pauwels R, Drazen JM. Leukotriene modifiers and Churg-Strauss syndrome: adverse effect or response to corticosteroid withdrawal? Drug Safety 1999; 4: 241-251. 
16. Barnes PJ. Inhaled glucocorticoids for asthma. $N$ Engl J Med 1995; 332: 868-875.

17. Busse WW. A comparison of inhaled versus oral corticosteroids as maintenance therapy in asthma. In: Schleimer RP, Busse WW, O'Byrne PM, eds. Inhaled glucocorticoids in asthma. New York, Marcel Dekker, 1997; pp. 481-492.

18. Pedersen SE. Efficacy and safety of inhaled corticosteroids in children. In: Schleimer RP, Busse WW, O'Byrne PM, eds. Inhaled glucocorticoids in asthma. New York, NY, USA, Marcel Dekker, 1997; pp. 551-606.

19. Jarjour S. Alternative anti-inflammatory and immuno- modulatory therapy. In: Szefler SJ, Leung DYM, eds. Severe asthma: pathogenesis and clinical management. New York, NY, USA, Marcel Dekker, 1996; pp. 333-369.

20. Churg A, Brallas M, Cronin S, Churg J. Formes frustes of Churg-Strauss syndrome. Chest 1999; 108: 320-323.

21. Priori R, Tomassini M, Magrini L, Conti F, Valesini G. Churg-Strauss syndrome during pregnancy after steroid withdrawal. Lancet 1999; 352: 1599-1600.

22. Bili A, Condemi JJ, Bottone SM, Ryan CK. Seven cases of complete and incomplete forms of Churg-Strauss syndrome not related to leukotriene receptor antagonists. J Allergy Clin Immunology 1999; 104: 1060-1065. 